\title{
Wanted: institutions for balancing global food and energy markets
}

\author{
Niek Koning • Arthur P. J. Mol
}

Received: 24 May 2009/Accepted: 27 May 2009 / Published online: 11 June 2009

(C) The Author(s) 2009. This article is published with open access at Springerlink.com

\begin{abstract}
The increasing demand for biomass for energy use is further escalating existing food security risks. Managing these risks is a task for global institutions. These should ensure timely investment in the world's capacity for producing biomass and balance the use of this biomass for foods and for non-foods. To achieve this, institutional arrangements for global food markets must fulfil two important goals: reduce the short-term price instability of food markets and prevent a structural scarcity of food in the long term. This paper analyses how agro-food markets, energy markets and biofuel markets are currently regulated. As this regulation is ill-suited to manage food price instabilities and balance food and non-food use of biomass, new institutions need to be put in place. A coordinated system of global commodity management - not unlike the Commodity Control Organization proposed by Keynes for the post-WWII era - is proposed to deal with these coming challenges.
\end{abstract}

Keywords Food security · Biofuel · Food prices · Agricultural policy $\cdot$ Energy policy

\section{Introduction}

Food prices have major effects on food security. High prices make food inaccessible for poor consumers. Low and unstable prices hamper investment that should increase employment and moderate the cost of food production in poor countries. Since the late 19th century, international

N. Koning $(\bowtie) \cdot$ A. P. J. Mol

Department of Social Sciences, Wageningen University, P.O.Box 8130, 6700 EW Wageningen, The Netherlands e-mail: Niek.koning@wur.nl agricultural prices have fluctuated downward. As a reaction, many countries have stabilized and/or supported their domestic agricultural prices. In most of them, rapid agricultural development contributed to overall growth, reducing poverty and food insecurity (Koning 2007; for Asian Green Revolution countries, Dorward et al. 2004). Conversely, poor countries that failed to stabilize and/or support farm prices have seen their agriculture stagnate. The plight of farmers was exacerbated by over-taxation and dumping practices of countries that failed to combine farm income supports with an adequate management of their supply. Agricultural stagnation dragged the rest of the economy with it, leaving large parts of the population poor and vulnerable to fluctuations in food prices.

After several decades with very low prices, the year 2008 saw a sudden spike in global food prices. Although prices have meanwhile come down again, this has rekindled concerns that the long-term decline in food prices might give way to increased scarcity. Population growth and an increasing consumption of livestock products may double the global demand for biomass for food up to mid-century. Whether the global supply will keep pace with this is uncertain (Koning et al. 2008; Rosegrant et al. 2006). One important reason for this is the competition from agro-fuels (crop-based biofuels). The production of these has strongly increased since 2000. At first, this was seen as a possibility to improve farm prices that had become too low to get agriculture in poor countries moving. However, the role of the agro-fuel boom in the 2008 price spike made clear that agro-fuels might also exacerbate food price instability and make food prices prohibitive for the poor (Banse et al. 2008a; Mitchell 2008; Rosegrant 2008).

To be sure, various strategies may moderate the risks that the evolution of agro-food markets involves for global food security. On the supply side, there are many possibilities for 
raising food production in developing countries (cf. InterAcademy Council 2004; World Bank 2007). More generally, there remains considerable room for increasing the global supply of food through sustainable yield increases, bio-refinement and new non-farm biomass production systems. On the demand side, an increase in food scarcity can be countered by policies that mitigate the increase in consumption. Most importantly, effective poverty reduction could moderate the growth of world population and the ensuing increase in demand. Poverty is the main factor that is holding back the decline in demographic fertility in many low-income countries. In addition, the growing consumption of livestock products that involve especially unfavourable feed conversion ratios, such as feedlot beef, could be mitigated. The development of effective meat substitutes is a possibility, but a shift to poultry or herbivore fish would also help (Koning et al. 2008).

Also with respect to biofuels, various options are available for protecting the food security of the poor. Governments could stop supporting first-generation agrofuels, and channel the development of bio-based non-foods towards feedstocks that minimally compete with food (e.g. waste, algae). At the same time, small-scale techniques for the decentralized pre-processing of biomass could be developed to allow small farmers to benefit from the growth in bio-based non-foods (Sanders et al. 2007).

However, key conditions for steering global food security safely through the storms are timely investment in global capacities for food production and stable international agricultural prices. The latter should be high enough to stimulate agricultural development in poor countries but not so high as to prevent sufficient access to food for poor consumers. In this respect, the rapid growth of agro-fuels poses a major challenge. Through them, food markets become closely related to energy markets, not just nationally but globally. This paper analyses which institutions are available, or missing but needed, for balancing food and energy markets with a view to safeguarding the food security of the world's poor.

The outline of the paper is presented in Fig. 1. We start with a more detailed discussion of the food security risks that follow from price movements in agro-food markets, paying special attention to effects of the emerging market for biofuel ("Food security at risk"). Then we survey the institutions for market regulation that currently exist in three markets. First, we review how the regulation of agricultural markets has evolved over time ("Regulation of agricultural markets"). Second, we consider the regulation of fossil fuel energy markets ("Regulation of fossil fuel markets"). And third, we review current developments in the regulation of the emerging markets for biofuels, which connect both preceding domains ("Regulatory void in biofuel markets"). "Conclusion: institutional requirements

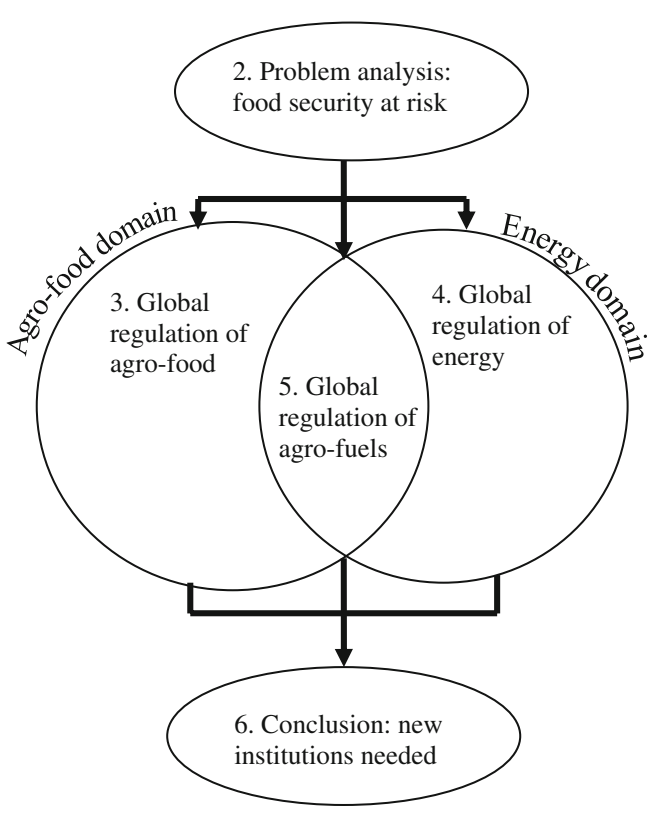

Fig. 1 Structure of the paper

for balancing agro-food and energy markets" concludes by indicating institutional solutions for balancing these various markets so as to safeguard global food security.

\section{Food security at risk}

Evolution of agricultural prices in the 20th century

Agricultural markets are prone to strong price instability. On the one hand, the demand and the short-term supply are priceinelastic. This implies that small surpluses cause steep price falls, while small shortages send prices skyrocketing. On the other hand, environmental and general-economic turbulence makes fluctuations in supply and demand volumes unavoidable. These conditions together cause strong fluctuations in prices. In addition, myopic expectations cause endogenous price fluctuations (Ezekiel 1938; Nerlove 1958). Such 'cobweb cycles' are well-known in regional pig markets ("pig cycle"). However, they also operate in wider agricultural markets (Díaz Jerónimo, 2006; also cf. Boussard et al. 2006). By way of illustration, Fig. 2 shows the long-term evolution of wheat prices in Britain and the US, as proxies for world market prices. The historical evolution (see graphs until 2007) shows strong fluctuations, which were caused by the interaction of exogenous shocks (in particular, major wars) and endogenous mechanisms.

Figure 2 also shows that decadal price fluctuations were movements along a longer-term trend. Before the Industrial Revolution, population growth sent the trend upwards. Scarcity of fertilizer restricted the increase in yields, high 


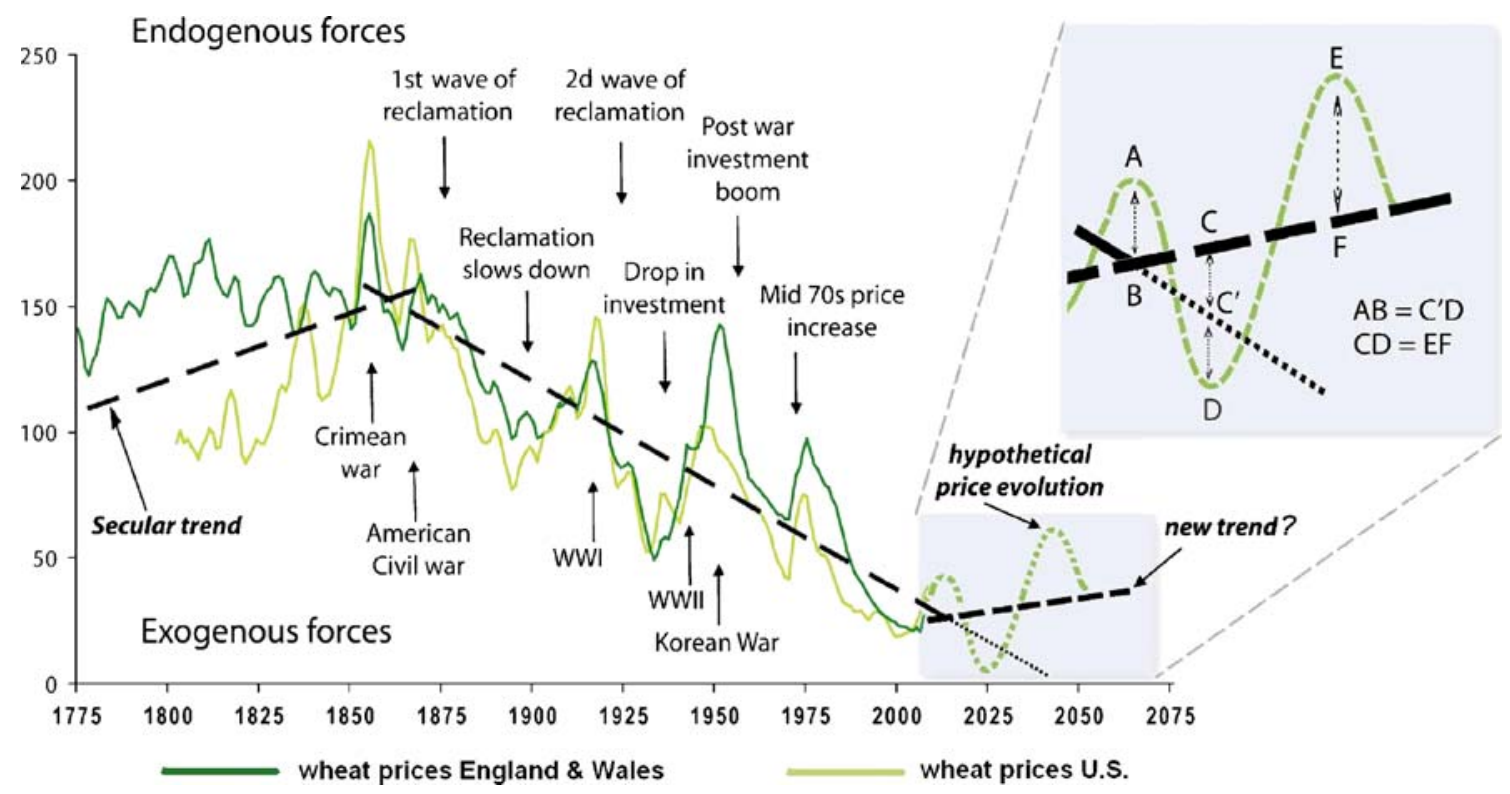

Fig. 2 Indexes of real wheat prices in the US and England \& Wales, 1775-2007, and hypothetical evolution after 2007. (Prices up to 2005 are 5-year moving averages, with $1901-05=100$. Prices in 2005-07 are

annual prices with the same base years. Sources: Mitchell 1975, 1990, 1993; USBC 1976; Eurostat various years; OECD 1990; USDA 2008; USBL 2008.)

transport costs made it costly to supplement local deficits through imports, and under-developed knowledge infrastructures slowed technical progress. Around 1875, these Malthusian constraints were broken. New fertilizers, the Transport Revolution, and scientific research removed the shackles on supply, while fossil fuels freed vast areas of land that had until then been used for non-food crops (Schultz 1945). Since then, agricultural prices have fluctuated along a downward trend. The latter did not just reflect a normal cost price that decreased over time by productivity growth. Agricultural markets rather leaned towards pricedepressing overproduction. This was because farmers responded to low earnings by tightening their belts and investing in new techniques that increased production (Cochrane 1959). In a free market, therefore, supply and demand were only balanced when low prices squeezed the margins that farmers had for investment. It meant that equilibrium was achieved through a slowdown of innovation rather than through a reallocation of labor and capital (Bairoch 1976; Koning 1994). A striking example was the near-total stagnation of productivity growth in the agriculture of Britain between 1875 and 1930, when this country kept to agricultural free trade in spite of falling world market prices (Koning 1994; Van Zanden 1991; Wade 1981).

New scarcity?

That food prices declined in the 20th century does not guarantee that they will decline in the future. Since the late 1960s, neo-Malthusian authors have been warning for a new impending food scarcity (Brown 1995; Ehrlich 1968; Meadows et al. 1972). Economists in established research institutions long contradicted these predictions (Bruinsma 2003; Mitchell et al. 1997; Rosegrant et al. 2001). Recently, however, some of them have become more cautious in assessing the global availability of food in the future (e.g. Rosegrant et al. 2006).

Between now and mid-century, the world population will increase from 6.5 billion to around 9 billion people. The demand for animal products may double, not least as a result of rising incomes in successful developing countries (Keyzer et al. 2005; Steinfeld et al. 2006). As a consequence, the global demand for biomass for food and feed may more than double. This expected demand in growth is not as large as that experienced in the second half of the 20th century, when a rapid response of the global supply still caused international agricultural prices to decrease. Therefore, the real question is whether the global supply of food will once more be able to keep up with the increase in demand.

This question can only be tentatively answered. On the one hand, we know that the main sources of agricultural growth in the 20th century are drying up. Only Africa and Latin America have significant reserves of suitable land. In several grain belts, freshwater supply for irrigation is running dry (Molden 2007; Rosegrant et al. 2002). And the increase in yield potentials of major food crops is increasingly being restricted by plant metabolic efficiency (cf. Hibberd et al. 2008; Yin and Struik 2007). On the other hand, the technical room for raising the global output of existing crop varieties is sufficient to provide an affluent 
diet to twice the world population that is expected by midcentury - even if competing claims and unavoidable losses are included in the analysis (Koning et al. 2008). Innovations like $\mathrm{C} 4$ rice, algae, mariculture, biorefinement, and attractive meat substitutes might further increase this margin in the future.

However, the full realization of the potential that technical scientists identify will be prevented by economic constraints (ibid.):

- Producers are profit maximizers. So diminishing returns make them stop short of achieving the maximum from the techniques they are familiar with. For instance, realizing the above mentioned technical potential for crop production would require a sixfold increase in the global irrigated area (ibid.). Diminishing returns to irrigation investment will make the real increase a far cry from this (many experts would be happy with 50\%).

- Pushing back diminishing returns requires considerable research investment to extend existing production functions. However, such investment is constrained by its profitability. In the 20th century, agricultural research gave high returns (Alston et al. 2000), but this was due to cheap fertilizer, and to the feasability, which is now being depleted, for breeding plants that could transform more fertilizer into harvested parts by improving plant architecture, crop duration and the timing of crop development. Whether research for realizing the remaining potential for raising food production will give comparable returns is highly uncertain.

- The progressive depletion of the world's reserves of fossil fuels and phosphate rock (Cordell 2008; Smil 2000) will raise the costs of many farm inputs, especially fertilizers. Compensating for this by improving efficiency is difficult. The energy efficiency of modern ammonia plants is approaching the chemical maximum (Jenssen and Kongshaug 2003; Smil 2001). An improvement of the efficiency of fertilizer-use will, in its turn, be complicated by the need to raise production on less suitable soils.

- In many developing countries, producers face less favourable input-output price ratios than their counterparts in developed countries, as well as higher risks and transaction costs. Therefore they may opt rationally for simple technologies that give a lower output per hectare, but which require fewer inputs for maintenance. (See the schematic representation in Fig. 3, which shows that with less favourable price ratios, profit maximization may require techniques that allow a lower maximum output.) As these countries contain a large part of the world's unused potential for farm production (Penning de Vries et al. 1995), the consequences for global food supply will be far-reaching.

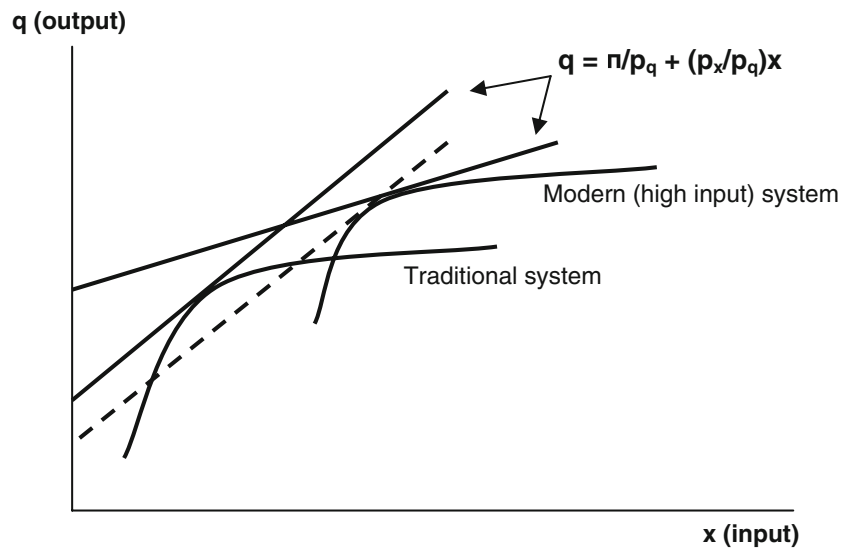

Fig. 3 Schematic representation of the selection of farm techniques in favoured and less-favoured areas. The straight lines are price lines with the ratio of input price $\left(\mathbf{p}_{\mathbf{x}}\right)$ and output price $\left(\mathbf{p}_{\mathbf{q}}\right)$ as slope. Profit (II) is maximized by selecting the point on production functions through which the price line with the highest intercept with the output axis can be drawn. For farmers in favoured areas (low ratios of input prices to output prices) this point is located on the production function of modern high input systems, but farmers in less-favoured areas will select traditional systems

Hence, as always in human history, global food supply will reach an economic ceiling long before the technical potential that may be perceived from the vantage point of the world's technological frontier has been exhausted. Adequate policies can push the ceiling upward, but surpassing it requires new breakthroughs that may be hard to realize. Seen in this light, the technical potential for feeding two or three times the expected world population does not exclude a trend change in the coming decades. The long-term decline in food prices might cease or give way to a new long-term increase.

\section{Influence of biofuels}

These concerns are exacerbated by the recent biofuel boom. Liquid biofuels were important in the Interbellum period especially in the US, but had largely been replaced with fossil fuels at the eve of WWII. They re-emerged strongly in Brazil in the 1970s, but elsewhere only from the turn of the millennium. Today, over $90 \%$ of liquid biofuels is bioethanol, mainly produced in Brazil (from sugarcane) and the US (from maize). Biodiesel is mainly produced in the EU, from rapeseed, sunflower- and other oilseeds. Brazil, the EU and the US together accounted for over $90 \%$ of global biofuel production in 2006. The recent boom in firstgeneration agro-fuels has several causes. One is "peak oil": environmentalists, major oil companies and academic energy specialists are warning that the increasing scarcity of fossil fuel makes it imperative to develop new energy sources. The oil price rise between 2004 and mid-2008 has 
given a further boost to biofuels - also because biofuels can use the existing infrastructure for oil or gas products (distribution and retailing systems, cars, combustion systems), which makes them more competitive than other alternative energy sources. Besides, the discussion on $\mathrm{CO}_{2}-$ caused global warming has created a favourable situation for the stimulation of alternative energy systems including biofuels. Furthermore, the dependence of fossil fuelimporting countries (especially the US and the EU) on producing countries that are seen as unreliable (Russia, the Middle East, Venezuela) generates pressures to lower this dependency. Finally, problems of agricultural surpluses and low farm incomes in many OECD countries have created a fertile ground for searching for new outlets for agricultural products.

There is widespread agreement that the rapid increase in the production of biofuels in Brazil, the US and the EU was one of the factors that contributed to the spike in food prices in the first half of 2008 (Banse et al. 2008a; Mitchell 2008; Rosegrant 2008). It has been claimed that biofuels have a stabilizing influence on agricultural markets by introducing a floor and a ceiling effect (Schmidhuber 2007). However, the levels at which these effects occur depend on energy prices. The latter are themselves highly unstable, which affects the validity of the argument. Various observers expect that biofuels will have an upward effect on international food prices in the years to come (OECD-FAO 2008). Banse et al. (2008b) project that the proposed $10 \%$ mandatory biofuel use in EU gasoline (draft EU directive on promotion of the use of energy from renewable sources) and biofuel initiatives of other countries will change a $13 \%$ decrease in cereal prices between 2001 and 2020 into a 6\% increase, and a $7 \%$ decrease in oilseed prices into a $19 \%$ increase. How the competition between foods and biobased non-foods will evolve in the longer term is highly unpredictable. Many people expect that biorefinement ('second-generation biofuels techniques') will moderate this competition because it will reduce the area requirements per unit of non-foods. However, these techniques will also reduce the cost price of non-foods, which will have the opposite effect (also cf. Meeusen and Van Tongeren 2006; OECD 2006). Moreover, new increases in energy prices will reinforce the competition between nonfoods and food.

\section{Governance needs}

Hence, we are confronted with two interrelated threats to future food security: food price instability and potential new scarcity of food. The development of crop-based biofuels has strengthened these threats. The possibility for the global supply of food to keep up with the growth in demand may vitally depend on global institutions that (i) ensure timely investment in the world's capacity for producing biomass, (ii) stabilize agricultural prices to facilitate this investment and protect the poor against sudden rises in food prices, and (iii) balance the use of biomass for food and non-foods.

In the next sections, we review the evolution of institutions for regulating the markets for agricultural products, fossil fuels and biofuels. We discuss to what extent these institutions may help to achieve the above aims. We start with the regulation of agricultural markets.

\section{Regulation of agricultural markets}

Market intervention and attempts at multilateral regulation

Since the regime change from scarcity to (over)abundance in international agricultural markets in the 19th century, ever more countries have intervened to stabilize and support their domestic farm incomes. Most West European countries started doing so in the late 19th century. All other OECD countries followed in the 1930s (Koning 2008; Tracy 1989). After the 1950s, many Asian developing countries followed their example (Dawe 2001; Francks et al. 1999; Kajisa and Akiyama 2005; Timmer 2002). These policies mostly enabled a rapid agricultural development that contributed to overall growth, reducing poverty and food insecurity (Dorward et al. 2004; Koning 2007). Conversely, poor countries that failed to stabilize and/or support farm prices have seen their agriculture stagnate. Agricultural stagnation dragged the rest of the economy with it, leaving large parts of the population poor and vulnerable to fluctuations in food prices (Koning and Smaling 2005).

Without supply management, however, national policies for supporting or stabilizing agricultural prices distorted world markets by causing import substitution and dumping. In the 1930s-1940s, therefore, the League of Nations, the U.S. Department of Agriculture, the FAO, John Maynard Keynes and others advocated a multilateral regulation of international markets through price bands, buffer stocks, and in some cases production and export controls (Chimni 1987; Henningson 1981; Keynes 1943). It led to the first attempts at international commodity agreements for major crops. In a similar vein, the General Agreement on Tariffs and Trade (1947) envisaged the regulation of agricultural markets through managed trade rather than free trade. It allowed countries to conclude commodity agreements to stabilize world markets (article $\mathrm{XX}$ ) and to support their own agriculture provided that they controlled their domestic production and exports (articles $\mathrm{XI}$ and XVI). 
Mercantilism and pseudo-liberalization

In the decades that followed, however, the US and the EU thwarted this pursuit of a multilateral regulation. While blocking supportive control agreements for tropical export crops (Chimni 1987; Maizels 1992), they protected their own farmers without respecting the GATT conditions that bound such support to production and export controls. As a consequence, both blocs were dumping increasing volumes on the world market. In the 1980s, the mutual dumping of grain and grain substitutes caused a trade conflict between the two powers. This dominated the agricultural negotiations during the Uruguay Round of GATT negotiations. After 6 years of stalemate, bilateral negotiations between the US and the EU led to a compromise (Blair House Agreement), which was enshrined in the WTO Agreement on Agriculture. It prescribed countries to reduce their price supports for agricultural commodities. At the same time, however, it exempted certain forms of direct payments, also from the original GATT obligation to couple supports to supply management (Koning 2008). Since then, both the US and the EU have been shifting from price support to direct payments to farmers, allowing them to continue exporting farm products for prices below their costs of production (Ritchie et al. 2003). The extent of this 'dumping in disguise' was widened by the abandoning of remaining production controls: the set aside programme in the US in 1996 (Ray et al. 2003), and the phasing out of the milk quotas in the EU as is happening today.

Although mercantilist interests played a prominent role in this policy change, it was accompanied by a discourse on "trade liberalization". This reflected a more general paradigm shift in economics and economic policies. The growth disturbances of the 1970s had discredited the "neoclassicalKeynesian synthesis" that had dominated the economics discipline in the first postwar decades, and that had advocated active government intervention for achieving socio-economic aims like social security and full employment. It catalysed a "microeconomic revolution" that reduced the role of government once again to the classical night watchman state. In agricultural economics, this revolution entailed the abandoning of an older institutionalist approach that had highlighted the rationale for government support (Gardner 1992). According to the new consensus, such support was unnecessary and could only hamper economic growth and hurt poor consumers. Studies based on computable general equilibrium models claimed that multilateral trade liberalization would benefit developing countries (e.g. Anderson and Martin 2005; Anderson et al. 2006). Trade liberalization was also expected to reduce price instability as it would allow harvest failures and bumper harvests in different places to cancel each other out (e.g. Bale and Lutz 1979). Besides, the idea was that private stock holding could take over the stabilizing function of public stocks. Accordingly, the World Bank and the IMF pressured many developing countries to abandon public stock holdings. Also, it was thought that futures markets could reduce price risks for smallholders in developing countries. The World Bank experimented with devices to allow smallholders to participate in these markets as an alternative for international commodity agreements which it deemed economically unviable. Last but not least, it was thought that private investment could take over the role of public investment in agricultural research. Part of the WTO agenda was the strengthening of intellectual property rights to stimulate private research investment.

Mercantilist interests seized upon the new economic orthodoxy, adopting a liberal-economic discourse to justify the shift to direct payments. The result was an uneasy marriage. More principled free-market economists were disappointed with actual reforms in developed countries. Nevertheless, their theories allowed these reforms to be justified as an intermediate step towards real liberalization, rather than to be denounced as a pseudo-liberal continuation of offensive protection.

\section{Short-term- and long-term effects}

In the short term, the policy reforms have made agricultural markets more prone to price fluctuations. External influences that cause changes in supply and demand do not always cancel each other out. Environmental disturbances like El Niño may have a global effect, and the same holds for global economic booms or recessions. Moreover, liberalization strengthens the effect of myopic expectations on prices. The major part of farm production is traded in domestic markets, where decreased price stabilization has increased the scope for cobweb cycling. Some agricultural economists (like Boussard's group in France; Boussard et al. 2006) predicted this effect, but their warnings went unheeded by policy makers and their mainstream colleagues. The running down of public stocks in the US and the EU as part of their policy reforms also reinforced price instability. Private stock holding does not compensate for this because it is less anti-cyclical. As has now become clear, rising prices may induce entrepreneurs to retain stocks in the expectation of further price increases, so that price rises are reinforced rather than moderated. Something similar holds for futures markets, which can only reduce price risks for producers if futures prices are not too far removed from spot market prices (Banse et al. 2008a). The speculation in these markets has become such that the two prices diverge and the underlying price instability is increased. Besides, experiments with arrangements to allow smallholder farmers in developing countries to participate in these markets have met with poor results. 
The opening of OECD markets may benefit larger farmers in agricultural exporting and middle-income countries like Australia or Brazil. However, it is questionable whether agricultural trade liberalization would stimulate the development in poor countries. Many poor countries themselves need protection to get their agriculture moving (Koning 2002; Koning and Smaling 2005). Besides, reduction in price support in OECD countries erodes the value of arrangements that give many poor countries preferential access to OECD markets (Panagariya 2005; Yu 2007).

In the longer term, "liberal" reform might precipitate a reversal in the secular trend in food prices. Increased price instability discourages timely investment in research, human capital and infrastructure. Direct payments stimulate the increase in agricultural production capacities less than price supports do. Additionally, they involve higher budget costs, strengthening pressures for reducing the level of farm income support. The cuts in public investment in agricultural research have similar effects. From 1976-1981 to 1991-2000, the growth of this investment fell from $4.5 \%$ to $1.6 \%$ yearly (Pardey and Beintema 2001; Pardey et al. 2006). This has not been compensated by private investment, whose growth rate also declined after the $1980 \mathrm{~s} .{ }^{1}$ Moreover, private research investment is one-sidedly focused on objectives like pesticide tolerance. Objectives like drought tolerance - important for raising production in many less-favoured areas - are being neglected (Pingali 2007).

The reduction in price stabilization also increases the risk that price fluctuations will interact with a change in the long-term trend in a way that may cause unnecessarily high rises in food prices. For example, it is widely assumed that the low prices and cuts on research expenditures in the 1980s-1990s have reduced investments in agriculture and that this has contributed to the recent price rise. Suppose that when the global recession is over, prices will rise again, as many observers expect. And suppose that this will prompt a rapid exploitation of the last margins for cheap increases in the global farm output that still exist in countries such as Brazil and Russia. After some years, this may induce a new price fall, which may once more squeeze longer-term investment in the world's carrying capacity for food production. If this were to coincide with a change in the long-term trend, the result might well be a period with stronger price rises than have taken place in the last few years. The undershooting of the outgoing trend investment would then involve a larger undershooting of the new trend, which would prompt a correspondingly large increase in prices above this trend (see right-hand part of Fig. 2). In

\footnotetext{
${ }^{1}$ Oral communication Nienke Beintema.
}

this admittedly worst case scenario, a tripling or quadrupling of grain prices cannot be excluded. Such a price rise would hardly affect food security in rich countries. However, it would wreak havoc in poor countries, and the effects would certainly be felt in other regions too.

\section{Regulation of fossil fuel markets}

By the growing use of biomass for energy production, agrofood markets are increasingly related to energy markets. Energy prices and their fluctuation are thus more directly affecting food prices. Hence, the governance of agro-food markets can no longer be isolated from that of energy markets. What institutions for regulating energy markets have evolved, and how successful are they in stabilizing energy prices?

Compared to agricultural commodities, energy commodities (i.e. oil and gas mainly) are much more subject to exchange on a world market, especially because production is limited to only a few countries. Oil was the first fossil energy source that was widely traded. Fluctuations in oil prices are politically sensitive in current energy-dependent societies, not unlike fluctuations in food prices. Some oil market speculation is directly related to the political stability of certain states. Concerns about this stability have from time to time driven up the price of oil. The oil market is exceptional in being so sensitive to the politics of volatile regions. Even the supply of natural gas is in general more secure, as it is not traded across oceans by tankers as extensively. Regionally, though, the production and piped transport of gas can also be tied up with political instability (Correljé and van der Linde 2006). Compared to agro-food production, however, the production and prices of fossil energy are only incidentally affected by environmental disturbances (such as hurricane Katrina).

As energy has increasingly become a crucial commodity for modern societies, most countries have installed national policies for securing energy supply and controlling prices, and many energy production and distribution companies have been publicly owned and managed. In resource-rich countries, domestic energy prices are kept artificially low for political and economic reasons, while export prices are set at a different level through taxes (dual pricing), amongst other things. Traditionally, energyimporting states have installed stocks to balance shortfalls in oil delivery, but less so for gas. Like public food stocks (see previous section), these stocks have diminished in recent years, making oil price fluctuations more immediate and stronger.

The "supermajors" (first the Seven Sisters, now the six largest multinational oil companies) have had an impact on international energy prices for quite some time. But with 
the establishment of the $\mathrm{OPEC}^{2}$ in 1960 and especially since the OPEC's political activism in the 1970s, the power of multinational oil companies to influence prices has decreased significantly. The large multinational companies currently control just $5 \%$ of world oil and gas reserves. OPEC states and OPEC state-owned companies control $50 \%$ of oil trade and produce about $40 \%$ of world oil (though only $16 \%$ of world natural gas). ${ }^{3}$ It is likely that the multinational companies will continue to lose power to state-owned and state-controlled companies (increasingly of non-OECD countries). In contrast to agro-food trade, rather than import barriers, export barriers (restrictions and taxes, sometimes differentiated to different markets) and dual (domestic and export) prices of energy exporting countries are debated in energy trade liberalization.

For a long time, fluctuations in international oil prices remained limited (cf. Fig. 4). However, between the early 1970s and the mid 1980s, and again since the late 1990s, oil prices have fluctuated widely. In the 1970s, OPEC policies and political instability of oil-exporting countries (e.g. Iran) were mainly responsible for limiting production and raising prices. However, recent price rises are attributed to several drivers: lack of stocks/reserves, political instability in oil-producing regions, lack of buffer production capacity due to poor investments, demand increases in emerging economies, and 'peak oil' (Wirl 2008). These factors are thought to explain why price rises are not always and immediately followed by offsetting increases in the supply (Correljé and van der Linde 2006). However, energy prices also react strongly to global economic developments, which may thereby exacerbate price spikes and price falls.

World energy trade is not subject to a public multilateral regulation comparable to the WTO Agreement on Agriculture. The WTO has no energy chapter and no energy rules, and for a long time, energy was considered as a special commodity that did not fall under a WTO regime. Since the 1970s, oil- and gas-importing countries have been demanding WTO regulation (focused on further liberalization of energy markets), in order to make their access to energy less vulnerable to political developments. While many no

\footnotetext{
$\overline{{ }^{2} \text { The OPEC }}$ is still the most powerful multilateral institution (basically a public cartel) that aims to control market prices of oil by regulating production, basically for the benefit of its 13 member states (Algeria, Angola, Ecuador, Indonesia, Iran, Iraq, Kuwait, Libya, Nigeria, Qatar, Saudi Arabia, the United Arab Emirates, and Venezuela).

${ }^{3}$ In late 2008, 15 major gas-producing and - exporting countries cooperating in the Gas Exporting Countries Forum, with headquarters located in Doha, Qatar, adopted a chapter to secure high gas prices. This is believed to have become an OPEC-like natural gas cartel.
}

longer consider energy ill-suited for WTO regulation, attempts to bring it under WTO ruling have had little success so far. The first reason is that about $50 \%$ of the energy products that are traded globally comes from nonWTO members. Secondly, in WTO accession processes, future members often aim to prevent - or demand to be excluded from - energy service sector liberalization, unbundling of energy monopolies, elimination of export taxes, and termination of dual prices. Thirdly, the world market, in the sense of a coordinating institution, has partly been replaced by bilateral or regional contracts by countries that thus try to secure their energy supply and stabilize their energy prices (e.g. gas contracts in Europe) (Selivanova 2007).

Following the instability in oil prices over the last decades, we see several calls for an international UN organization to bring order into the world oil (and to a lesser extent gas) market (cf. Glenn and Gordon 2002; Kirton 2003). Such a UN organization should organize long-term contracts that provide security of supply related to security of demand. These calls move beyond the old plea for liberalization from oil-importing countries and unilateral attempts at influencing oil prices by exporting countries. They are underpinned by environmental arguments (related to international climate policy) and by arguments linked to energy source diversification (the need to shift to renewables). Nevertheless, the contours of an international energy organization have yet to be seen.

\section{Regulatory void in biofuel markets}

Crop-based biofuels (agro-fuels) link agricultural markets and energy markets. Through them, movements in energy prices can influence food prices. Policies that stimulate or discourage agro-fuels have effects in both markets. In this section, we discuss the evolution of agro-fuel markets and consider how they are regulated.

Liquid biofuels have re-emerged from the turn of the millennium. (Only in Brazil, bioethanol was already widely produced in the 1970s.) During the first years of the new millennium, biofuels have been produced primarily for domestic markets, with hardly any cross-border trade. Governments in many countries have been stimulating these national markets in numerous ways. These include large R\&D programmes; mandatory targets for biofuel use in gasoline and diesel; the subsidization through tax reductions and credit facilities of farmers, biofuel producers, and various demand-side actors; experiments with transport technologies and programmes; and so on and so 


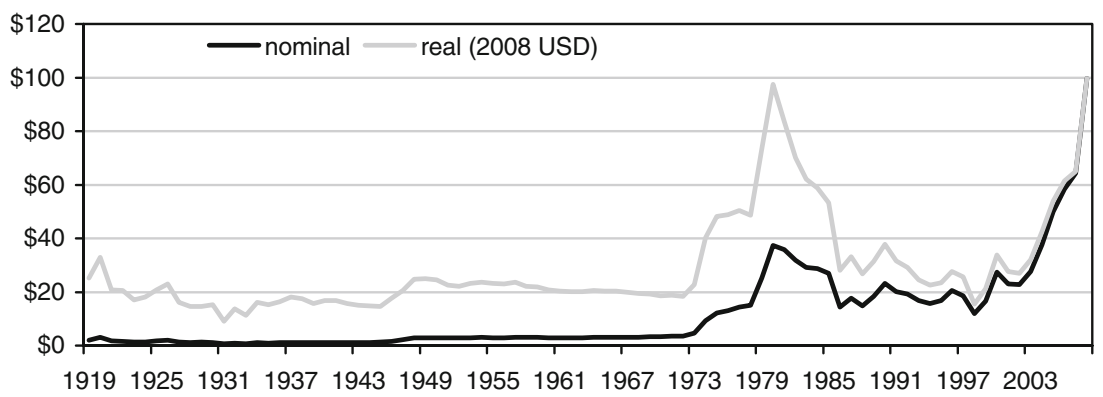

Fig. 4 Average annual price of crude oil, 1991-2008 (data source: http://www.eia.doe.gov/)

forth (Doornbosch and Steenblik 2007; Mol 2007). The prices of biofuels were strongly influenced by these policies. At the same time, protective measures against foreign competition prevented serious international trade in biofuels for several years. Because biofuel markets resembled fossil energy markets to some extent, and because one of the reasons for biofuel development was energy security, an interest of governments in price setting, protection and market development was to be expected. Yet there are two major differences from oil. Firstly, while oil is produced in a limited number of countries/regions, biofuels - or feedstock for biofuels - can be produced in many more countries. Secondly, for current biofuel feedstock production, fertile land (with inputs and water) is a prerequisite, which leads to competition with food.

Recently, international trade in (feedstock for) biofuels has been increasing. Besides energy companies and state agencies, farmer cooperatives, agribusiness and car companies have become involved in this trade. Estimates are that around $10 \%$ of the global biofuel production was traded cross-border in 2006. In addition, palm oil, soy and other feedstock for especially the production of biodiesel is traded internationally. ${ }^{4}$ While we cannot yet speak of a globalized biofuel economy, and protectionism continues to exist, it is clear in which direction the development is going. The mandatory targets of liquid biofuel use in OECD countries are driving increasing international trade, as many countries cannot meet their domestic demand. Increasingly, developing countries are moving into energy crop production. But their lack of hard and soft infrastructures might limit them to exporting feedstock, so that they would not fully benefit from their comparative advantage in biomass production by becom-

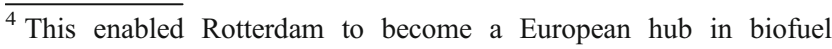
processing, although there is no abundance of cropland in the neighbourhood.
}

ing exporters of (higher valued) biofuels (Mol 2007). Foreign direct investment could prevent this. Indeed, US, Brazilian and European businesses see major commercial opportunities in developing countries. They are seizing these opportunities by supplying advanced equipment, setting up production and processing facilities, and investing in energy plantations in biomass-rich regions such as sub-Saharan Africa and Southeast Asia. However, the positive or negative consequences for local economies are not yet clear.

The emergence of a global market for biofuels has induced attempts at global collaboration on standards and specifications related to biofuel quality. In addition, it has led to a demand for ending protection and for multilateral liberalization. There are some developments in this direction and one can expect the WTO to try to become the leading framework for global biofuel regulation, in close relation to its agricultural chapter (Howse et al. 2006; Motaal 2008). According to some, the biofuels issue could even help to overcome the existing deadlock in the agricultural trade negotiations in the WTO. It could help to legitimize the existence of the WTO, which is going through a difficult time now that bilateral trade agreements are partly replacing WTO agreements. However, how biofuels will fit into the existing WTO trade regime is not at all clear. Are they going to be defined as agricultural, industrial, or energy goods? This has consequences for the subsidies allowed and the kind of import tariffs they can be subject to (Motaal 2008). Governments of biofuelproducing countries are increasingly convinced that import barriers need to be broken down, but they seem less willing to lift subsidies to their domestic primary producers, processors, and users. And what would be the consequences of a WTO-conform trade regime for domestic regulations and standards (e.g. mandatory use of biofuels, fuel content requirements, environmental conditionalities) (Dufey 2006; Loppacher 2005)? Up till now these questions have not been clarified. 
At the moment, the EU is arguably the most active regional government institution that develops biofuel policies which, though primarily meant for its internal market and member states, have significant consequences for international markets. The emphasis in EU biofuel policies (e.g. the 2008 draft renewable energy directive) is very much on stimulating biofuels, a little on the environmental side effects of biofuels, but not at all on the relation between biofuels and food prices.

Meanwhile, globally traded biofuels are also becoming subject to private forms of governance. Standard-setting agencies such as the International Standard Organization are focusing on biofuels. Multinationals are developing corporate policies and coordinating international commodity chains and networks. We are also witnessing a blossoming of round tables, private labelling initiatives, and international networks and arrangements in which a variety of economic and civil society actors are working together, often assisted by governments, to facilitate trade and investment (Verdonk et al. 2007; van den Hombergh 2008; Mol 2009). These emerging private governance arrangements to some extent address environmental side effects of large-scale biofuel production. Further coordination of the mushrooming private, public-private and public (inter)national initiatives (of individual companies, NGOs, multi-sector coalitions, nation-states etc.) could certainly help to mitigate such side effects and even to tackle some of the social issues in biofuel production. However, how these initiatives could address the influence of biofuels on international food prices remains entirely unclear.

In conclusion, a global market for biofuels is emerging, and it is strongly linked to both energy and agro-food markets. This biofuels market is still subject to significant national stimulation and regulation through mandatory market creation, subsidies, import tariffs, and the like. But the tendency is towards cautious liberalization - perhaps in a WTO framework. Neither the national policies nor this incipient liberalization are addressing the international competition between biofuels and food staples and its consequences for global food security.

\section{Conclusion: institutional requirements for balancing agro-food and energy markets}

What conclusions can be drawn from this review of the regulation of agro-food, energy and biofuel markets with a view to food security? Global food security is best served by stable agricultural prices. These prices should neither be so high as to inhibit access to food by the world's poor in the short term, nor so low as to inhibit timely investment in the world's carrying capacity for biomass production in the longer term. Because agro-food and energy systems are becoming increasingly inter-related, stabilizing agro-food prices within adequate price bands cannot be done without stabilizing energy prices. Our analysis suggests that current global institutions are ill-designed for balancing agro-food and energy markets, and thus for securing food security.

Keeping the world market prices of major crops within desirable price bands requires arrangements that adjust the production of biobased non-foods to the situation of food markets. Private standards and certification schemes for biobased non-foods are not up to this task. No matter how important such arrangements may be for improving the environmental sustainability and the social impacts of biobased non-foods in the areas where they are produced, they are little suited for regulating the competition between fuel and food at the global level.

The WTO framework is likewise ill suited for this purpose, at least as long as the WTO agenda is guided by the objective of trade liberalization. As we have argued above, trade liberalization does not redress important causes of price instability in agricultural markets. Neither will market deregulation help to keep the average prices of major farm staples at desirable levels. To keep the world market prices of major food staples within desirable price bands, rather than mere trade liberalization, one would need a multilateral system based on managed trade. In it, public buffer stocks could be used for stabilizing world market prices (also cf. von Braun and Torero 2008). Tax or other restrictions could be imposed on biobased non-foods especially those derived from crops — when the world market prices of major food staples exceed a ceiling. Maximum export quotas and minimum import quotas could be imposed on high- and middle-income countries to defend a price floor. These quotas could be made saleable between countries to allow adjustment to shifts in comparative advantage.

Because of the increasing competition between foods and biobased non-foods, such arrangements cannot easily be introduced on a commodity-by-commodity basis, as with the older international commodity agreements. The same consideration also pleads against the idea of leaving the regulation of biofuel markets to a sectoral UN International Energy Organization or a UN World Environmental/Sustainability Organization. Rather what is needed, in our view, is a coherent system for coordinated supply management in several markets. This was the objective of UNCTAD's Integrated Program for Commodities in the 1970s, and of the Commodity Control Organization that Keynes proposed in his 1943 blueprint for the post-war economic order (Keynes 1943; Maizels 1992). The marriage of mercantilism and economic orthodoxy that inspired the liberalizing agenda for agricultural trade in the 1980s has got these 
ideas into the bad books of the international political community. Nevertheless, the coming competition between food, feed and fuel, and the warning that has been given by the 2008 price spike, may be reasons for reconsidering the issue. The current ambivalence towards under-regulated markets that has followed the financial crisis also creates a more favourable climate for such a reflection.

Acknowledgements We thank Gertjan Becx, Martin van Ittersum, Roel Jongeneel and two anonymous referees for valuable comments and support. The responsibility for the content of this paper remains that of the authors.

Open Access This article is distributed under the terms of the Creative Commons Attribution Noncommercial License which permits any noncommercial use, distribution, and reproduction in any medium, provided the original author(s) and source are credited.

\section{References}

Alston JM, Chan-Kang C, Marra MC, Pardey PG, Wyatt TJ (2000) A meta analysis of rates of return to agricultural R\&D: ex pede Herculem? Washington, D.C.: IFPRI Research Report, 113

Anderson K, Martin W (eds.) (2005) Agricultural trade reform and the Doha Development Agenda. New York \& Washington, D.C.

Anderson K, Martin W, van der Mensbrugghe D (2006) Distortions to world trade: impacts on agricultural markets and farm incomes. Rev Agric Econ 28(2):168-194

Bairoch P (1976) Commerce extérieur et developpement économique de lÉurope au XIXe siècle. Paris

Bale M, Lutz E (1979) The effect of trade intervention on international price instability. Am J Agric Econ 61(3):512-516

Banse M, Nowicki P, van Meijl H (2008a) Why are current world food prices so high ? The Hague: LEI Report 2008-040

Banse M, van Meijl H, Tabeau A, Woltjer G (2008b) Will EU biofuel policies affect global agricultural markets? Eur Rev Agric Econ 35(2):117-141

Boussard J-M, Gérard F, Piketty MG, Ayouz M, Voituriez T (2006) Endogenous risk and long run effects of liberalization in a global analysis framework. Econ Model 23:457-475

Brown LR (1995) Who will feed China? A wake-up call for a small planet. Norton, New York

Bruinsma J (2003) World agriculture: towards 2015/2030: an FAO perspective. Earthscan, London

Chimni BS (1987) International commodity agreements: a legal study. Croom Helm, London

Cochrane WW (1959) Farm prices - myth and reality. Minneapolis

Cordell D (2008) The story of Phosphorus: Missing global governance of a critical resource, Preliminary findings from 2 years of doctoral research. Institute for Sustainable Futures, University of Technology Sydney, Australia and Department of Water and Environmental Studies, Linköping University, Sweden. Paper prepared for SENSE Earth System Governance, VU University Amsterdam, 24th-31st August, 2008

Correljé A, van der Linde C (2006) Energy supply security and geopolitics: a European perspective. Energy Policy 34:532-543

Dawe D (2001) How far down the path to free trade? The importance of rice price stabilization in developing Asia. Food Policy 26(2):163-175

Díaz Jerónimo P (2006) Global food projections: a price dependent investment in agricultural research scenario. MSc thesis Wage- ningen University: Agricultural Economics and Rural Policy Group \& Development Economics Group

Doornbosch R, Steenblik R (2007) Biofuels: is the cure worse than the disease? Paris: OECD (SG/SD/RT(2007)3)

Dorward A, Kydd J, Morrison JA, Urey I (2004) A policy agenda for pro-poor agricultural growth. World Dev 32:73-89

Dufey A (2006) Biofuels production, trade and sustainable development: emerging issues. International Institute of Environment and Development, London

Ehrlich PR (1968) The population bomb. Ballantine Books, New York

Ezekiel M (1938) The cobweb theorem. Q J Econ 53:225-280

Francks P, Boestel J, Kim CH (1999) Agriculture and economic development in East Asia: from growth to protectionism in Japan, Korea and Taiwan. Routledge, London and New York

Gardner BL (1992) Changing perspectives on the farm problem. J Econ Lit 30:62-101

Glenn JC, Gordon TJ (2002) Creating a better world: 15 global challenges. Foresight 4(5):15-37

Henningson BE jr. (1981) United States agricultural trade and development policy during world war II: the role of the Office of Foreign Agricultural Relations. Ph.D. diss., University of Arkansas

Hibberd JM, Sheehy JE, Langdale JA (2008) Using C4 photosynthesis to increase the yield of rice: rationale and feasibility. Curr Opin Plant Biol 11(2):228-231

Howse R, van Bork P, Hebebrand C (2006) WTO disciplines and biofuels: opportunities and constraints in the creation of a global marketplace. International Food and Agricultural Trade Policy Council, Washington, D.C

InterAcademy Council (2004) Realizing the promise and potential of African agriculture: science and technology strategies for improving agricultural productivity and food security in Africa. Amsterdam

Jenssen TK, Kongshaug G (2003) Energy consumption and greenhouse gas emissions in fertiliser production. The International Fertiliser Society Proceedings 509

Kajisa K, Akiyama T (2005) The evolution of rice price policies over four decades: Thailand, Indonesia and the Philippines. Oxf Dev Stud 33(2)

Keynes JM (1943) The international regulation of primary products. Reprinted in D. Moggridge (Ed.), Collected writings of John Maynard Keynes, London (1980): MacMillan \& Cambridge University Press

Keyzer MA, Merbis MD, Pavel IFPW, van Wesenbeeck CFA (2005) Diet shifts towards meat and the effects on cereal use: can we feed the animals in 2030? Ecol Econ 55:187-202

Kirton JJ (2003) Governing Globalization: The G8's Contribution for the Twenty-First Century. Revised version of a paper prepared for a conference on Russia within the "Group of Eight," sponsored by the Institute for Applied International Research, Hotel Metropole, Moscow, April 11-12, 2003 (https://tspace. library.utoronto.ca/retrieve/1158/KirtonMoscow2003.pdf)

Koning N (1994) The failure of agrarian capitalism: agrarian politics in the UK, Germany, the Netherlands and the USA, 1846-1919. Routledge, London and New York

Koning N (2002) Should Africa protect its farmers to revitalise its economy? International Institute for Environment and Development, London. IIED Gatekeeper Series, 105

Koning N (2007) What can be learned from the history of developed countries. In: Koning N, Pinstrup-Andersen P (eds) Agricultural trade liberalization and the least developed countries. Dordrecht, pp 197-215

Koning N (2008) The evolution of farm policies: a long-term global perspective. Paper for the COST workshop on "State agricultural policies: causes, implementation and consequences", 3-5 June 2008, Möschberg/Grosshöchstetten 
Koning N, Smaling E (2005) Environmental crisis or 'lie of the land'? The debate on soil degradation in Africa. Land Use Policy 22(1):3-11

Koning NBJ, van Ittersum MK, Becx GA, van Boekel MAJS, Brandenburg WA, van den Broek JA, Goudriaan J, van Hofwegen G, Jongeneel RA, Schiere JB, Smies M (2008) Long-term global availability of food: continued abundance or new scarcity? NJAS Wageningen Journal of Life Sciences, 55(3)

Loppacher LJ (2005) The conflicting international trade law governing products of biotechnology: the case of biofuels. JIBL 2 (1):54-61

Maizels A (1992) Commodities in crisis: the commodity crisis of the 1980 s and the political economy of international commodity policies. Clarendon, Oxford

Meadows DH, Meadows DL, Randers J, Behrens WW (1972) The limits to growth: a report for the club of Rome's project on the predicament of mankind. Universe Books, New York

Meeusen M, van Tongeren F (2006) Understanding the factors which determine biomass availability. In: Kuiper L (ed) Quick-scans on upstream biomass; Yearbook 2004 and 2005. Biomass Upstream Consortium. Wageningen, pp 219-237

Mitchell DO, Ingco MD, Duncan RC (1997) The world food outlook. Cambridge University Press, Cambridge

Mitchell D (2008) A note on rising food prices. World Bank, Development Projects Group, Policy Research Working Paper 4682

Mol APJ (2007) Boundless biofuels? Between vulnerability and environmental sustainability. Sociol Rural 47(4):297-315

Mol APJ (2009) Environmental authorities and biofuel controversies. Environmental Politics, 18 (fortcoming)

Molden D (ed) (2007) Water for food, water for life: a comprehensive assessment of water management in agriculture. Earthscan, London

Motaal DA (2008) The biofuels landscape: is there a role for the WTO? J World Trade 42(1):61-86

Nerlove M (1958) Adaptive expectations and cobweb phenomena. Q J Econ 72:227-240

OECD (2006) Agricultural market impacts of future growth in the production of biofuels. OECD Working Party on Agricultural Policies and Markets, Directorate for Food, Agriculture and Fisheries, Paris

OECD-FAO (2008) Agricultural outlook 2008-2017: highlights. Paris \& Rome

Panagariya A (2005) Agricultural liberalisation and the least developed countries: six fallacies. The World Economy 29(8):1277-1299

Pardey PG, Beintema NM (2001) Slow magic: Agricultural R\&D a century after Mendel. International Food Policy Research Institute (IFPRI), Washington, D.C

Pardey PG, Beintema N, Dehmer S, Wood S (2006) Agricultural research: a growing global divide?. International Food Policy Research Institute IFPRI, Washington, D.C

Penning De Vries F, van Keulen H, Rabbinge R (1995) Natural resources and limits of food production in 2040. In: Bouma J, Kuyvenhoven A, Luyten JC, Zandstra HG (eds) Eco-regional approaches for sustainable land use and food production. Kluwer Academic Publishers, Dordrecht, pp 65-87

Pingali P (2007) Will the gene revolution reach the poor? Lessons from the Green Revolution. Wageningen University. Mansholt Lecture, 26 January 2007

Ray DE, De la Torre Ugarte DG, Tiller KJ (2003) Rethinking US agricultural policy: changing course to secure farmer livelihoods worldwide. Agricultural Policy Analysis Center, University of Tennessee, Knoxville

Ritchie M, Murphy S, Lake M (2003) United States dumping on world agricultural markets. Institute for Agriculture and Trade Policy, Minneapolis

Rosegrant MW, Paisner MS, Meijer S, Witcover J (2001) Global food projections to 2020: emerging trends and alternative futures. International Food Policy Research Institute (IFPRI), Washington, D.C
Rosegrant MW, Cai X, Cline SA (2002) World water and food to 2025: dealing with scarcity. International Food Policy Research Institute (IFPRI), Washington, D.C

Rosegrant MW, Msangi S, Sulser T, Ringler C (2006) Future scenarios for agriculture: plausible futures to 2030 and key trends in agricultural growth. Washington, D.C: Background Paper for the World Development Report 2008. International Food Policy Research Institute (IFPRI)

Rosegrant MW (2008) Biofuels and grain prices, testimony before the US Senate Committee on homeland security and governmental affairs, May 7, 2008

Sanders J, Scott E, Weasthuis R, Mooibroek H (2007) Bio-refinery as the bio-inspired process to bulk chemicals. Macromol Biosci 7:105-117

Schmidhuber J (2007) Impact of an increased biomass use on agricultural prices, markets and food security. In: Haverkort A, Bindraban P, Bos H (eds) Food, fuel or forest? Opportunities, threats and knowledge gaps of feedstock production for bio-energy. Plant Research International, Wageningen, pp 2126

Schultz TW (1945) Agriculture in an unstable society. New York \& London

Selivanova Y (2007) The WTO and energy. WTO rules and agreements of relevance to the energy sector. International Centre for Trade and Sustainable Development, Geneva

Smil V (2000) Phosphorus in the environment: natural flows and human interferences. Annu Rev Energy Environ 25:53-88

Smil V (2001) Enriching the earth: Fritz Haber, Carl Bosch, and the transformation of world food production. MIT, Cambridge

Steinfeld H, Gerber P, Wassenaar T, Castel V, Rosales M, de Haan C (2006) Livestock's long shadow: environmental issues and options. Food and Agriculture Organization (FAO), Rome

Timmer CP (2002) Food security and rice price policy in Indonesia: the economics and politics of the food price dilemma. Indonesian Food Policy Program Working Paper, 7. Bappenas/USAID/DAI Food Policy Advisory Team

Tracy M (1989) Government and agriculture in western Europe 18801988. Harvester Wheatsheaf, New York

Van den Hombergh H (ed) (2008) Multi-stakeholder commodity round tables: Lessons from civil society engagement. Summary report of workshop results and recommendations. Amsterdam: IUCN (NP.net, Nature and Power Knowledge and Learning Ne

Van Zanden JL (1991) The first Green Revolution: the growth of production and productivity in European agriculture, 1870-1914. Econ Hist Rev 44:215-239

Verdonk M, Dieperink C, Faaij APC (2007) Governance of the emerging bio-energy markets. Energy Policy 35:3909-3924

Von Braun J, Torero M (2008) Physical and virtual global food reserves to protect the poor and prevent market failure. IFPRI Policy Brief 4, Washington, D.C.

Wade WW (1981) Institutional determinants of technical change and agricultural productivity growth: Denmark, France and Great Britain, 1870-1965. New York

Wirl F (2008) Why do oil prices jump (or fall)? Energy Policy 36:1029-1043

World Bank (2007) World development report 2008. World Bank, Washington, D.C

Yin X, Struik PC (2007) Crop systems biology - an approach to connect functional genomics with crop modelling. In: Spiertz JHJ, Struik PC, Van Laar HH (eds) Scale and complexity in plant systems research. Springer, Dordrecht, pp 63-73

$\mathrm{Yu} W$ (2007) Improving market access in agriculture for the African least-developed countries: deepening, widening, broadening and strengthening trade preferences. In: Koning N, PinstrupAndersen P (eds) Agricultural trade liberalization and the least developed countries. Springer, Dordrecht, pp 129-152 


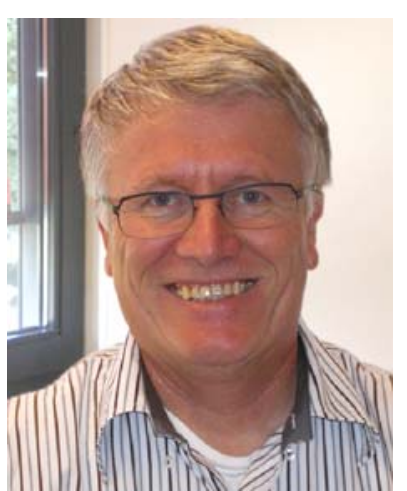

Niek Koning (1948) is senior lecturer in the Agricultural Economics and Rural Policy Group and the Sustainable Development and Food Security Group at Wageningen University. His research focus is the long term evolution of agriculture, institutions and politics in an international-comparative perspective. He wrote many research articles on farm policy issues and problems of agricultural markets. He is the author of The Failure of Agrarian Capitalism: Agrarian politics in the United Kingdom, Germany, the Netherlands and the USA 1846-1919 (Routledge 1994) and the editor (together with Per Pinstrup-Andersen) of Agricultural trade liberalization and the least developed countries (Springer 2007).

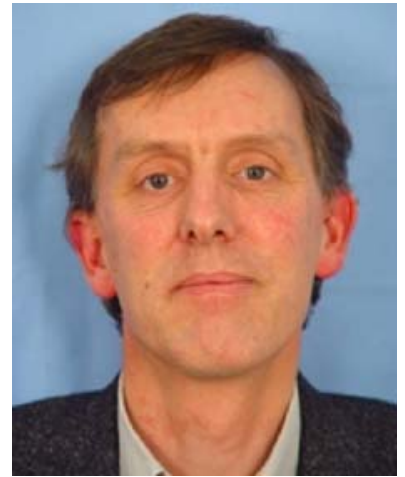

Arthur P. J. Mol (1960) is chair and professor in environmental policy within the Department of Social Sciences at Wageningen University, the Netherlands. He works extensively in Southeast and East Asia, East Africa, and the EU. His research interests are in social theory and the environment, globalization, informational governance, greening production and consumption, and environment and development. He is at the editorial board of eight international journals and two book series. His latest books are Environmental Governance in China (edited together with Neil Carter; Routledge, 2007), Partnerships, Governance and Sustainable Development. Reflections on theory and practice (edited together with Pieter Glasbergen and Frank Biermann; Edward Elgar, 2007) and Environmental Reform in the Information Age. The contours of informational governance (Cambridge UP, 2008). 